\title{
Comparative Analysis of Pak-Indo Press Role toward Annexation of Special Status of Kashmir: From War to Peace Perspective
}

${ }^{a}$ Muhammad Ahmed Qadri, ${ }^{b}$ Rooh Ul Amin Khan, ${ }^{c}$ Muhammad Abbas

${ }^{a}$ Former Dean, Faculty of arts and social sciences, University of Karachi, Sindh, Pakistan

Email: prof.qadri@gmail.com

${ }^{\mathrm{b}}$ Assistant Professor, Department of Media \& Communication Studies, International Islamic University, Islamabad, Pakistan

${ }^{\mathrm{c}}$ Department of Media \& Communication Studies, International Islamic University, Islamabad, Pakistan

\begin{tabular}{|c|c|}
\hline ARTICLE DETAILS & ABSTRACT \\
\hline History: & Indo-Pak Conflict on the territory of Kashmir started with Pakistan's \\
\hline Accepted 30 April 2021 & released in August 1947. At that time all the states were given the choice \\
\hline Available Online June 2021 & $\begin{array}{l}\text { of choosing India or Pakistan. The then princely states rulers had to } \\
\text { make their option. There have been some preliminaries, they said when }\end{array}$ \\
\hline Keyu & selecting both states; one is the geographical proximity and the one was \\
\hline Indo-Pak Conflict, Conflict & for the public ambition. In October 1947, given the fact that Kashmir was \\
\hline $\begin{array}{l}\text { Journalism, Peace Journalism, } \\
\text { Kashmir Dispute }\end{array}$ & $\begin{array}{l}\text { predominantly Muslim state that opted for the state of Pakistan, while } \\
\text { the Kashmir's Maharaja chose India in support. This choice was }\end{array}$ \\
\hline JEL Classification: & $\begin{array}{l}\text { perceived by the Pakistani government as fraudulent, unfair and entirely } \\
\text { unrecognized judgement. Furthermore, the religious orientation of more }\end{array}$ \\
\hline D74, J52 & $\begin{array}{l}\text { Kashmiri inhabitants can be seen as another factor in this conflict } \\
\text { (Qumber, Ishaque and Shah 2017). This study aims to explore framing }\end{array}$ \\
\hline DOI: $10.47067 /$ real.v4i2.157 & $\begin{array}{l}\text { from war to peace-journalism after the Indian attempt of August 5, } \\
\text { 2019, to annex the special status of Kashmir, in two English elite } \\
\text { newspapers i.e. Daily Dawn, a Pakistani newspaper and the other is } \\
\text { Hindustan Times an Indian Newspaper. The study explores news stories } \\
\text { on front page along with editorials of these newspapers to understand } \\
\text { how these newspapers covered and framed the issue? }\end{array}$ \\
\hline
\end{tabular}

(C) 2021 The authors. Published by SPCRD Global Publishing. This is an open access article under the Creative Commons AttributionNonCommercial 4.0

Corresponding author's email address: prof.qadri@gmail.com

\section{Introduction}

Kashmir is situated in the Himalayan Mountains, as the convergence of Pakistan, Afghanistan, India and China. The Mughal emperors of India called Kashmir paradise through the elegance of the environs. The total area of Kashmir status which is erstwhile British India the princely state numbered 86,023 square miles. Kashmir has been a desolate paradise in the past 7 decades. In the current of the inhabitants were stuck in a bitter dispute between India and Pakistan (Cheema 2015).

Standoff between the two countries have battered the region for than seven decades. Indo-Pak 
Conflict on the territory of Kashmir started with Pakistan's released in August 1947. At freedom time in 1947, all the subcontinent Indian princely states were given that the choice of the choosing with India or Pakistan jurisdiction consider them did not got the option of unilateral conquest, for the British Crown would not allow it. With that in mind the then princely states rulers should have make their option. There have been some preliminaries, they said when selecting both states; one is the geographical proximity and the one was for the public ambition. In October 1947, given the fact that Kashmir was predominantly Muslim state that opted for the state of Pakistan, Kashmir's Maharaja chose India in support. This choice was perceived by the Pakistani government as fraudulent, unfair and entirely unrecognized judgement. Furthermore, the religious orientation of more Kashmiri inhabitants can be seen as another factor in this conflict (Qumber, Ishaque and Shah 2017).

During the Indian and Kashmir time of partition like Aksai Chin, there was surface field of 222,236 kilometers square. Ten percent of Kashmir had of that region, 14.4 percent Jammu and 75.6 percent of the border districts. In accordance with 1941 records Kashmir had a population of 4.02 billion, $77 \%$ Muslims and 20\% Hindus while the remaining 3\% were other communities. $45.62 \%$ of this initial state area encompasses India today, for Pakistan 35.15 \% so what is it China encompasses 19.23\%. the Control Line (LoC) separates Jammu and Kashmir into total 778 kilometers territory and it is an unquestioned 198 kilometers boundary in between India and Pakistan Punjab region of the state. There is an undefined line in the Siachen zone, about $150 \mathrm{~km}$ separating India and Pakistan (Cheema 2015).

National troops landed in Kashmir on 27 October 1947 to push away Pakistan's tribal invaders. The arrival took place within a contentious treaty between the Hindu ones then rulers from state and of New Delhi. The war had ended upon the withdrawal of tribal, India had not withdrawn its forces and formed the foundation of the Kashmir dispute. Every year in Kashmir, October 27 is also observed as a strike to protest the involvement of national powers in the territory and demand withdrawal of Indian forces. (Gadda 2014).

In addition, in response to the Kashmir problem, numerous escalations between India-Pakistan have been witnessed which have further deteriorated the relations between both nations. Below are a couple of them mentioned:

- The first 1947-48 Kashmir war which caused in the liberation of the majority of AJ\&K.

- The 1965 India-Pakistan war was also fought on the premise of the Kashmir's independence, but ended up in stalemate.

- The 1999 Kargil conflict had a clear connection with Kashmir's status quo.

- The 2002 Indian escalation and the subsequent deployment of more than 0.7 million Indian troops and more than 0.3 million Pakistani troops in the nuclear environment in South Asia, so as a result the United Nation and major powers intervened to de-escalate it. (Qumber, Ishaque and Shah 2017).

Despite an unprecedented safety lockdown and house arrest of elected leaders in an Indian occupied Kashmir, India ruling Bharatiya Jannata Party (BJP) cleared Kashmir of their unique status on the directives of Indian President in hurry on Monday for seven decades. After abolishing Article 370 from Indian Constitution, citizens from rest of India now have the freedom to purchase land in the occupied territory and permanently settled there. All Kashmiri and critics of nationalist-led Hindu government in India interpret the move as an attempt to dilute the population of Muslim majority with Hindu settlers in Kashmir, including defense matters. Foreign relations and communications, Article 
370 also limited Indian parliament's power to pass legislation in the country. As the move was being discussed by India's parliament, 8,00o Central Reserve Police Force (CRPF) were transferred to Indian Occupied Kashmir from various parts of India. Also, in high alert were the Indian Army and the Air Force. (Dawn.com August 5, 2019).

\section{Peace-Oriented Journalism}

Conflict arise because of conflicting objectives, which are often the product of deprivation of basic human needs including cultural and national identity, equality and opportunities in life, according to Johan Galtung. Scholars agree that media are powerful element of the society that have a significant impact on how conflict intensify and resolve. As per Peace Media Researcher Majid Tehranian and as many other experts have concluded, the media can be agent of violence if the right approaches are implemented, this way they can also serve peaceful ends (Hussain 2014).

According to Galtung, peace journalism is about making the subjugated elements of truth, audible and recognizable. Lunch and McGoldrick acknowledged that Galtung was targeted for peace journalism in our reports what is it called to be an "agenda journalism" or at least it is an effort to "engage". They argue that the gatekeeper position of the journalist means that there is an agenda on any story. Hanitzsch claims that war-oriented journalism involves many sides in conflict area, which causes conflict, solution of it found on the battlefield, it is a zero-sum-one hand gains and the other hand to it defeats and yet news reports conclude only with visible violence and consequences, including fatalities, injuries and physical harm. Hanitzsch contrarily stated that "peace of conflict journalism" examines history of the conflict setting up contradictions to make the audience appears straightforward. He claims that the peace journalism on both sides is finding reasons and ways out of conflict and is giving voice to all critics' view. "Peace or Conflict Reporting shows the pain of propaganda, efforts to cover up and blames on all sides and shows the pain of all conflicting parties. Because of its focus to the remedies, this form of crisis journalism pays particular attention to peace efforts and reports on post war developments (Siraj n.d.).

\section{War-Oriented Journalism}

From study, peace journalism was developed which indicates that conflict news sometimes has a value bias towards violence. It also provides realistic ways to address this imbalance by delivering news in both traditional and alternative media, as well as engaging with competing journalistic, media practitioners, listeners, and organizations.

Johan Galtung suggested this concept. Other words for this specific interpretation conflicts include peace journalism, resolution journalism which is prone to confrontation, positive license of conflicts, and global news.

\section{Problem Statement}

Revoking Article 370 and 35A from the Constitution of India is against the self-determination and spiritual emotions of Muslims of Indian Held Kashmir. The revoke is also against the resolution of United Nation General Assembly (UNGA) that Kashmir is a disputed territory.

So, Indian act of revoking special status of the disputed territory can escalate India and Pakistan toward nuclear wars as both countries are capable of nuclear weapons, which can sabotage the peace of the whole region as well as it can put the whole world into danger. 


\section{Objectives of the Study}

Traditional and electronic media play a vital role for reporting conflicts of all kind and power in today's global world. The general public is frequently going abroad with nothing to no choice but to count on their sources which could mean to be deeply deceptive as the public has little knowledge of the controversies that happen across the press and the news. That saying, the World is increasingly media dominated and the world moved astray. Ideally, the role of the media is to provide the coverage of the conflict that may draw significant international community concern. It may seem impossible to track the conflict as humanely as possible in the sense of the ongoing conflict due to political or other influences that form the language of the message and people may not be motivated to question those constructed messages aren't feel compelled to challenge those build narratives that not only produce but cultivate the narrative of war and violence. In addition, media reporting could prove fiercer than the will of the public and the governorship, thereby rendering the electronic media and newspapers as an entity that could complicate preliminary settlement of the dispute. Indian and Pakistanis prefer to structure the way they think about each other through media and press endorsed narrative. Most importantly, both countries' media reports on the Kashmir issue shape common people's perceptions in both countries significantly by delivering coverage from various angles. Media of Pakistan presents the mass killing and suffering for Kashmiri people, such as human rights, violation, causalities and migrations in and outside the valley with the support of Kashmir's local press and media. Most notably, it is precisely Pakistani media that calls international community attention. While reports of Indian media which tells the situation partly, establishing ideological difference between India and Kashmir, the true picture of Kashmir is largely untold. Such conflict-covering practices have contributing to the rising sense of alienation among Kashmiris. Rather than debating nationalism, militarizing the territory and Indian national media; pro-freedom deals with the issue of Kashmir as an internal security issue, following the governments security-centered that Kashmir is an integral part of that Kashmir is a constituent part of India; so-called Pakistani funded rebels cause unrest. The biases, tendencies and stereotypes in Indian electronic and print media all in all were the root causes of being the largest escalator in the Kashmir dispute in Indian media and the press (Riaz, Shah and Ahmad 2018).

This study aims to know about the Pak-Indian state's statements, public opinion about the amendment in constitution, and Kashmiris people perceptions on both sides about the annexation of Article 370 which provide special status to the valley. It also aims to know about the coverage of Indian constitution amendment about Kashmir status in Pak-Indian press.

\section{Theoretical Framework}

Galtung $(1986,1998)$ used since the 1970 as the term "peace-journalism" two opposing modes of war were reporting were created, namely "peace or conflict journalism" and "war or violence journalism". His classification of war journalism and peace journalism is based on four broad linguistic orientation and practices; peace/conflict, truth/propaganda, people/elites, solution/differences. War journalism, on the other hand, is based, in war/aggression, propaganda, politicians and victory. Peace journalism aims to denounce the conflict by giving both sides the black and white, and to de-escalate by emphasizing peace and conflict resolution as much as aggression. Peace journalisms seek to minimize the divide between adversaries by refusing to repeat facts that demonize one side and set the stage. War or Violence Journalism reports about the arena of conflict, focusing on who gets the upper hand in the war. It has a zero-sum coverage: bases primarily on visible violence and visible consequences (Siraj n.d.).

\section{Framing Theory}

The idea of framing relates to the practice of setting the agenda but extends the analysis by 
concentrating on the nature of the problems at hand, rather than on a particular subject. Framing theory is based on the idea that the media focuses attention on certain things and then positions them into a context of meaning. Framing is an important subject, because it can have a great impact and hence principle of framing expanded to companies as well.

Essentially, framing theory assumes that how somethings is presented to the viewer (the socalled "frame") affects people's choices on how to interpret the material. Frames are abstractions designed to organize or structure the meaning of messages. In terms of the frame, the most common use of frames is the news or media position on the information they convey. They are thought to manipulate the audience's interpretation of the news, and it could be viewed as a second-level agendasetting type not only informing the viewer what to think about (agenda-setting theory), but also how to think about it (second-level agenda-setting, framing theory).

Goffman first put forward the idea, under the title Frame Analysis. He put forward that through their primary context, people view what is going on in their planet. This system is known to be key, as the consumer takes it for granted. The usefulness as a frame is not based on other frameworks.

Goffman notes that within primary systems, there are two distinctions: human and social. All play the role of helping people understand the data. And their interactions can be interpreted in a larger sense of society. The discrepancy between the two is workable.

\section{Research Questions}

RQ-1: Which newspaper provides more coverage to the abrogation of Article 370?

RQ-2: From peace and war-oriented journalism perspective, how Pakistani and Indian press covered the abrogation of article 370 ?

\section{Results}

RQ-1: Which newspaper provides more coverage to the abrogation of Article 370?

\section{Dawn:}

Editorials:

Total $=8$

News Stories:

Total $=30$

\section{Hindustan Times:}

Editorials:

Total $=6$

News Stories:

Total $=47$ 
Table: Distribution of News Stories by War to Peace Journalism

\begin{tabular}{|c|c|c|c|}
\hline Newspaper & $\begin{array}{l}\text { War Journalism No. of } \\
\text { Stories (\%) }\end{array}$ & $\begin{array}{l}\text { Peace Journalism No. } \\
\text { of Stories }(\%)\end{array}$ & Total No. of Stories \\
\hline $\begin{array}{l}\text { Dawn } \\
\text { News } \\
\text { Editorials }\end{array}$ & $\begin{array}{l}24(80 \%) \\
3(37.5 \%)\end{array}$ & $\begin{array}{l}6(20 \%) \\
5(62.5 \%)\end{array}$ & $\begin{array}{l}30 \\
8\end{array}$ \\
\hline $\begin{array}{l}\text { Hindustan Times } \\
\text { News } \\
\text { Editorials }\end{array}$ & $\begin{array}{l}38(80.85 \%) \\
1(16.67 \%)\end{array}$ & $\begin{array}{l}9(19.14 \%) \\
5(83.33 \%)\end{array}$ & $\begin{array}{l}47 \\
6\end{array}$ \\
\hline
\end{tabular}

RQ-2: From peace and war-oriented journalism perspective, how Pakistani and Indian press covered the abrogation of article 370 ?

The news stories of the Dawn and Hindustan Times were totally tilted towards war journalism; however, the editorials case was totally different as peace perspective were high there. From headlines to intro, and from main body to the story ending Dawn's solo focus were to report atrocities, human rights violations, Pakistani politicians and military leadership rhetoric, which were totally warmongering statements. Dawn reported $80 \%$ of its news stories from war-oriented perspective, while only $20 \%$ percent of its news stories were tilted toward peace-oriented journalism. Furthermore, its editorials were better as its editorials have $37.5 \%$ war-oriented and $67.5 \%$ peace-oriented approach.

On the other hand, Hindustan Times reporting were also war oriented, they ignored the United Nation General Assembly Resolutions but covered the issue from the development perspective. Contrarily, HT too reported the Indian politicians and military leadership statements as it is as they said. HT reported $80.85 \%$ of its news stories from war-oriented journalism perspective, while $19.14 \%$ from peace-oriented journalism perspective. Similarly, its editorials have $16.67 \%$ war-oriented journalism, however, 83.33\% peace-oriented journalism.

\section{Conclusion}

The results indicated that the news stories of the Dawn and Hindustan Times were totally tilted towards war journalism. Though, with regard to editorials, it was absolutely dissimilar as peace perspective was high there. The main focus of Dawn newspapers was to report atrocities, human rights violations, Pakistani politicians and military leadership rhetoric, which were totally war-mongering statements. The editorials of Dawn were also better as its editorials have less war-oriented and more peace-oriented slant. In contrast, the Hindustan Times reporting was also war-oriented, they ignored the United Nations General Assembly Resolutions but covered the issue from the development perspective. Contrarily, Hindustan Times also reported the Indian politicians and military leadership statements with same wordings. The news stories of Hindustan Times were more war-oriented journalism perspective, while less from peace-oriented journalism approach. Similarly, its editorials presented less war-oriented journalism, and presented much peace-oriented journalism.

As both countries carry nuclear weapons and their most of the population living below the poverty line, hospitals are running out of its capacities, most of the children are out of school, child labor is at peak. So, the media of the both countries are needed to follow peace-oriented journalism instead of promoting war and to push this region into more trouble and poverty. 


\section{References}

Cheema, Musarat Javed. "Pakistan - India Conflict with Special Reference to Kashmir ." South Asian Studies , 2015: 45-69.

Dawn.com. India revokes occupied Kashmir's special autonomy through rushed presidential decree. Dawn.com, August 5, 2019.

Gadda, Danish Nabi. "'Partial Journalism'-A study of national media of India and Kashmir conflict." Trends in Information Management (TRIM), 2014: 13-23.

Hussain, Shabbir. "Reporting on Terror: Why are the voices of peace unheard?" Conflict and Communication Online, 2014.

Qumber, Ghulam, Waseem Ishaque, and Syed Jawad Shah. "Kashmir Crisis: A Critical Analysis of IndoPak Intercession." Global Social Sciences Review (GSSR, 2017: 67-78.

Riaz, Saqib, Babar Hussain Shah, and Shakil Ahmad. "KASHMIR ISSUE AND PAK-INDIAN PRESS: CONTENT ANALYSIS OF LEADING NEWSPAPERS." ISSRA Papers Volume-X, 2018: NA.

Siraj, Syed Abdul. "War or peace journalism in elite us newspapers: exploring news framing in Pakistan-India conflict." n.d. 